\title{
Vacuum Aspiration of the Uterus in Therapeutic Abortion
}

\author{
A. E. R. BUCKLE, ${ }^{*}$ F.R.C.s., F.R.c.o.G. ; MARY M. ANDERSON, ${ }^{*}$ M.R.C.o.G. ; K. C. LOUNG, $\dagger$ M.R.c.o.G.
}

\begin{abstract}
ummary: A prospective study of vacuum aspiration $\checkmark$ in 400 cases of therapeutic abortion is described showing that the procedure was quick, involving little blood loss in most cases, and that the complication rate was low. The routine use of this method in therapeutic abortion is recommended.
\end{abstract}

\section{Introduction}

Evacuation of the gravid or recently gravid uterus is used in the therapeutic termination of pregnancy, in cases of incomplete abortion, and in the evacuation of hydatidiform mole. The technique of dilatation of the cervix, followed by piecemeal removal of the contents, with curettage, is standard and has changed little over the years. Complications of the procedure include excessive trauma to the cervix, perforation of the uterus, haemorrhage, incomplete emptying of the uterus, and infection. Alternative methods of evacuation of the gravid uterus for the purposes of therapeutic abortion include the insertion of laminaria tents, intra-amniotic injection of hypertonic saline or glucose, the injection of Utus paste into the uterine cavity (Lachelin and Burgess, 1968), and, more recently, evacuation by the use of negative pressure (Černoch, 1960; Cernjak, 1963; Chalupa, 1964; Melko, 1964; Vladov, Ivanov, Angelov, and Rakilovska, 1965; Nilsson, 1967. Peretz, Grunstein, Brandes, and Paldi, 1967). One of the few reports from the United Kingdom on the use of the latter method has been the article by Kerslake and Caser (1967), which contains an excellent review of the historical background of evacuation of the uterus by negative pressure, the methods used, and their personal results. Diggory (1969) reported on a large series of therapeutic abortions, though only seven of the cases were managed by vacuum aspiration.

With the advent of the Abortion Act 1967, which came into effect in April 1968 in England, Wales, and Scotland, gynaecologists in active practice rightly surmised that the number of patients seeking therapeutic termination of pregnancy would sharply increase, and it was decided that this would be a convenient time to begin a prospective study of vacuum aspiration in the management of vaginal termination of pregnancy.

\section{Patients and Methods}

Only patients in whom vaginal termination by vacuum aspiration was performed have been included in the series, and the figures therefore exclude all patients managed by either intra-amniotic hypertonic saline injection or hysterotomy. The method has also been used in two cases of hydatidiform mole (Table I), and the success with these cases leads us to support the contention of Peretz et al. (1967) that it is the method of choice for evacuation of the uterus in this condition. Some cases of incomplete abortion have also been managed by vacuum aspiration, but the numbers are not large as we have felt it unwise to use the method with constantly changing junior staff.

Equipment.-A Matburn $₫$ electric pump capable of exerting a negative pressure of $760 \mathrm{~mm}$. of mercury was used. To

\section{* Consultant.}

tRegistrar.

Department of Obstetrics and Gynaecology, Lewisham General Hospital, London S.E.13. SObtainable from Matburn Surgical Equipment Limited, 6 Vere Street,
London, W.1. this is attached the rubber tubing leading to the twin bottles of the Bierer apparatus. $\$$ From the latter, thick wide-bore rubber tubing leads to the varying-diameter Bierer metal suction curettes, with outer diameters of $8,10,12$, and 14 $\mathrm{mm}$. Hollow glass or plastic curettes may be used (A. Černoch, personal communication, 1967).

\section{Technique}

Standard premedication and general anaesthesia are used and the patient is given $0.5 \mathrm{mg}$. of intravenous ergometrine before being brought into the operating-theatre. After preliminary vulval preparation and towelling, the vagina is painted with aqueous chlorhexidine solution, the bladder emptied, and the patient examined to determine the size and position of the uterus. The anterior lip of the cervix is grasped with a vulsellum forceps and dilatation begun, using Hawkins Ambler dilators, dilatation continuing until a dilator one size larger than the chosen size of metal suction curette has been reached. The size of metal suction curette used is normally the $8 \mathrm{~mm}$. in pregnancies up to 6-7 weeks, $10 \mathrm{~mm}$. for pregnancies of $8-9$ weeks, $12 \mathrm{~mm}$. for pregnancies of 10-11 weeks, and $14 \mathrm{~mm}$. for pregnancies over 12 weeks.

The requisite metal suction curette is then introduced and moved slowly over the uterine walls, the negative pressure being taken up to, though rarely beyond, $500 \mathrm{~mm}$. Hg. The end of the suction curette may occasionally block with placental tissue, in which case the latter may be removed separately with sponge-holding forceps. As suction continues the uterine wall is felt to come actively in contact with the curette, a feeling vastly different from that experienced when the uterus is being evacuated by sponge-holding forceps and curette. The experienced operator can judge from the sensation transmitted from the suction curette to the hand when the uterine contents have been evacuated. We have followed the procedure with curettage to confirm that the uterus is empty. After completion of the operation the patient is returned to the ward and given 5 units of oxytocin injection (Syntocinon) intramuscularly, and discharge from hospital takes place either on the evening of operation or on the following morning. Follow-up depends on what arrangements have been made for subsequent contraception, the patients being referred to their general practitioner, to the hospital family-planning clinic, or to a family-planning clinic of their own choosing.

\section{Current Series}

The technique of vacuum aspiration has been used on 409 successive occasions, the indications being listed in Table I.

TABLE I.-Indications for Vacuum Aspiration

Therapeutic termination of pregnancy Incomplete abortion ..
Hydatidiform mole

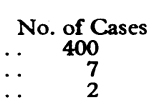

The succeeding figures relate only to the cases of therapeutic termination of pregnancy. Our main headings under which we have placed patients undergoing termination of pregnancy 
(Table II) do not attempt to follow those on the statutory notification forms, cases being put under one or other heading according to the main indication. Most cases fall under the social and psychiatric-social groups. As might be expected a high percentage are unmarried (Table III), there

TABLE II.-Indications for Therapeutic Abortion

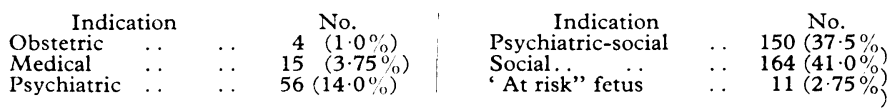

TABLE III.-Age and Marital Status of Patients

\begin{tabular}{|c|c|c|c|c|c|c|c|c|c|c|}
\hline & & \multicolumn{8}{|c|}{ Age in Years } & \multirow{2}{*}{ Tota } \\
\hline & & 15 & $15-19$ & $20-24$ & $425-29$ & $930-34$ & $35-39$ & $940-44$ & $45+$ & \\
\hline $\begin{array}{l}\text { Single } \ldots \\
\text { Married .. } \\
\begin{array}{l}\text { Divorced, } \\
\text { widowed }\end{array} \\
\quad \ldots \\
\end{array}$ & $\begin{array}{l}\cdots \\
\cdots \\
\text { or } \\
\cdots\end{array}$ & $\frac{7}{-}$ & $\begin{array}{r}79 \\
1 \\
1\end{array}$ & $\begin{array}{r}73 \\
31 \\
6\end{array}$ & $\begin{array}{l}21 \\
43 \\
11\end{array}$ & $\begin{array}{r}7 \\
53 \\
6\end{array}$ & $\begin{array}{r}4 \\
36 \\
4\end{array}$ & $\begin{array}{r}1 \\
12 \\
2\end{array}$ & $\begin{array}{r}- \\
-\end{array}$ & $\begin{array}{r}192 \\
178 \\
30\end{array}$ \\
\hline Total & . & 7 & 81 & 110 & 75 & 66 & 44 & 15 & 2 & 400 \\
\hline
\end{tabular}

being considerably increased social pressure on this group of patients.

Blood loss at operation will obviously be related to the duration of pregnancy, the ease of dilatation of the cervix, and the time taken over the procedure. Vacuum aspiration has been completed in less than five minutes in 346 cases $(86.5 \%)$, in 5 to 10 minutes in 51 cases $(12.8 \%)$, and has taken over 10 minutes in only three cases. Blood loss was sma!l in most cases (Table IV), and heavier loss was not necessarily encountered in cases of longer gestation. Most patients were discharged within 24 hours of operation (Table V). Those remaining after three days had either one or other of the listed complications (Table VI) or had been sterilized at the time of vacuum aspiration.

TABle IV.-Blood Loss in Relation to Period of Gestation

\begin{tabular}{|c|c|c|c|c|c|c|c|c|c|c|c|c|c|}
\hline \multirow{3}{*}{\multicolumn{2}{|c|}{$\begin{array}{l}\text { Gestation Period } \\
\text { in Weeks }\end{array}$}} & & & & & \multicolumn{4}{|c|}{ Blood Loss (ml.) } & & & & \\
\hline & & \multicolumn{2}{|c|}{100} & \multicolumn{2}{|c|}{$100-200$} & \multicolumn{2}{|c|}{$200-300$} & \multicolumn{2}{|c|}{$300-400$} & \multicolumn{2}{|c|}{$400-500$} & \multicolumn{2}{|c|}{$500+$} \\
\hline & & P. & M. & P. & $M$ & P. & M. & P. & M. & P. & M. & P. & M. \\
\hline $\begin{array}{l}4-6 \ldots \\
6-8 \ldots \\
8-10 \\
10-12 \\
12-14 \\
14+\ldots\end{array}$ & $\begin{array}{l}\ldots \\
\cdots \\
\cdots \\
\cdots\end{array}$ & $\begin{array}{r}3 \\
51 \\
16 \\
4 \\
- \\
\end{array}$ & $\begin{array}{r}1 \\
36 \\
32 \\
7 \\
4 \\
\end{array}$ & $\begin{array}{r}-13 \\
21 \\
8 \\
1 \\
\end{array}$ & $\begin{array}{r}- \\
13 \\
30 \\
13 \\
3 \\
1\end{array}$ & $\begin{array}{l}-5 \\
5 \\
6 \\
5 \\
\end{array}$ & $\begin{array}{r}-6 \\
12 \\
11 \\
3 \\
\end{array}$ & $\begin{array}{r}- \\
2 \\
5 \\
2 \\
3 \\
\end{array}$ & $\begin{array}{r}-1 \\
6 \\
9 \\
1 \\
\end{array}$ & $\begin{array}{r}- \\
1 \\
6 \\
1 \\
\end{array}$ & $\begin{array}{r}-1 \\
3 \\
17 \\
5 \\
\end{array}$ & $\begin{array}{c}- \\
1 \\
6 \\
4 \\
1\end{array}$ & $\begin{array}{l}- \\
3 \\
7 \\
6 \\
3\end{array}$ \\
\hline $14+\ldots$ & & \multicolumn{2}{|c|}{154} & \multicolumn{2}{|c|}{103} & \multicolumn{2}{|c|}{49} & \multicolumn{2}{|c|}{29} & \multicolumn{2}{|c|}{34} & \multicolumn{2}{|c|}{31} \\
\hline
\end{tabular}

P. = Primigravid. $\quad$ M. $=$ Multigravid

TABle V.-Duration of Hospital Stay

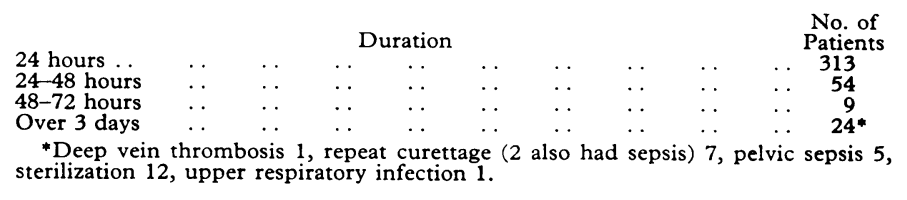

TABLE VI.-Complications Encountered

Uterine perforation

Postoperative pelvic sepsis

Superficial venous thrombosis

Deep vein thrombsi

Haemorrhage in excess of $500 \mathrm{mi}$. Blood replacement

Other fluid replacement

*These cases are not included in the series as they required suture of the uterine perforation and hysterotomy.

\section{Discussion}

Evacuation of the gravid uterus may not be an easy procedure even for the skilled operator, and there can be few gynaecologists who have not spent uneasy minutes during the operation. Experience with the vacuum aspirator has led to simplification of the technique, for, as Nilsson (1967) pointed out, less cervical dilatation is necessary, the operation is technically easy, and the procedure is probably less traumatic to the uterine mucosa. In his series there were 199 cases of therapeutic termination, with a rise in temperature in one case, bleeding requiring transfusion in six cases, and incomplete evacuation in one case. Kerslake and Caser (1967) also reported a low complication rate in their 70 cases and felt that the method was a satisfactory and non-traumatic method of inducing abortion. Peretz et al. (1967) concluded, in their series of 500 cases of suction evacuation (80 of which were for the purpose of therapeutic abortion), that the method improved the technique and results of evacuation of the gravid uterus, though they pointed out that blockage of the metal suction curette by placental tissue may occur, that there exists the risk of mechanical failure of the pump, and that occasionally it may be difficult to maintain the vacuum pressure owing to leakage around the collection bottles.

From our experience we agree that the method has considerable advantage over dilatation and curettage, in that a lesser degree of cervical dilatation is necessary, that the procedure is much quicker, and that the blood loss is moderate in most cases. In addition, the complication rate is very low, though two cases of uterine perforation occurred, which were unrecognized until suction yielded omentum in the end of the suction curette. These cases occurred early in the series and are excluded from the figures as vacuum aspiration was abandoned. Though curettage was carried out at the conclusion of vacuum aspiration as a standard method of management, we were not impressed by the amount of material obtained and would not advise its routine use. In common with other European workers we would recommend vacuum aspiration for use in therapeutic abortion in primigravidae up to the twelfth week of pregnancy and in multigravidae up to the fourteenth week of pregnancy.

\section{REFERENCES}

Černjak, A. A. (1963). Zdaravookhranenie Belorussii, 9, 28. Quoted by

Kerslake and Caser (1967).
Černoch, A. (1960). Ceskoslovenská Gynekologie, 25, 306.

Chalupa, M. (1964). Zentralblatt für Gynakologie, 86, 1803.

Diggory, P. L. C. (1969). Lancet, 1, 873.

Kerslake, D., and Caser, D. (1967). Obstetrics and Gynaecology, 30, 35

Lachelin, G. C. L., and Burgess, D. E. (1968). Fournal of Obstetrics and Gynaecology of the British Commonwealth, 75, 1173.

Melks, E. I. (1964). Akusherstovo $i$ Ginekologiya, No. 6, p. 133.

Nilsson, C. A. (1967). Acta Obstetrica et Gynecologica Scandinavica, 46, 501 .

Peretz, A., Grunstein, S., Brandes, J. M., and Paldi, E. (1967). American fournal of Obstetrics and Gynecology, 98, 18.

Vladov, E., Ivanov, I., Angelov, A. and Rakilovska, I. (1965). Gynaecologia, 159, 54 . 